\title{
Ebelik Bölümü Öğrencilerinin Empatik Eğilim Düzeylerinin Belirlenmesi
}

\author{
Determination of Empathic Tendency Levels of Students Receiving Education in the \\ Department of Midwifery
}

\author{
Hediye BEKMEZCI ${ }^{\mathrm{a}}$, Çiğdem Büşra YURTTAŞ ${ }^{\mathrm{a}}$, Hava ÖZKAN $^{\mathrm{a}}$
}

ÖZET Amaç: Ebelik Bölümü öğrencilerinin empatik eğilimlerini değerlendirmek amaciyla gerçekleştirilmiştir. Yöntem: Tanımlayıcı türde olan araştırmanın örneklemini, Sağlık Bilimleri Fakültesi Ebelik Bölümünde 2013-2014 öğretim y1lında öğrenim gören 175 öğrenciden gönüllü olarak araştırmaya katılan 150 öğrenci oluş̧urmuş̧ur. Veriler, araştırmacılar tarafından oluşturulan "Tanıtıcı Bilgi Formu" ve "Empatik Eğilim Ölçeği" kullanılarak toplanmıştır. SPSS paket programında ortalama, yüzdelik, $t$ testi ve varyans analizi ile değerlendirilmiştir. Bulgular: Araştırma kapsamındaki öğrencilerinin yaş ortalamasının $20.05 \pm 1.48$ olduğu, \%40.0'ının birinci sınıf olduğu, \%83.3'ünün okul öncesi eğitim almadığı, \%48.7'sinin en uzun süre ilde yaşadığı, \%74.0'ının orta düzeyde gelire sahip olduğu, \%79.3'ünün çekirdek aileye sahip olduğu, \%75.4'ünün aile içinde demokratik, güven verici ortamda yetiştirildiği ve \%49.3'ünün akademik başarısının orta seviyede olduğu saptanmıştır. Öğrencilerinin \%52.0'sinin daha önce empatik eğilim hakkında bilgisi olmadığı ve empatik eğilim hakkında bilgi alanlar içinde \%93.1'inin üniversitede ders olarak aldığı saptanmıştır. Sonuç: Öğrencilerin tanıtıcı özellikleri ve empatik eğilim hakkında bilgi durumları ile empatik eğilim puan ortalamaları arasında anlamlı fark olmadığı belirlenmiştir. Öğrencilerin empatik eğilimlerinin orta düzeyde olduğu tespit edilmiştir.

Anahtar Kelimeler: Empati, empatik eğilim, ebelik öğrencileri, ebelik eğitimi.

\begin{abstract}
Objective: This study was conducted to assess the empathic tendencies of students receiving education in the Department of Midwifery. Method: The sample group of this descriptive study consisted of 150 midwifery students who voluntary to participate in the study among 175 students receiving education in the Department of Midwifery at the Faculty of Health Sciences in the school year of 2013-2014. The data were collected using the "Introductory Information Form", which was formed by the researchers, and the "Empathic Tendency Scale". It was assessed by using the mean, percentage, $t$ test and the analysis of variance in the SPSS package software. Results: It was determined that students included in the study had an age average of $20.05 \pm 1.48,40.0 \%$ were first grade students, $83.3 \%$ had not received a preschool education, $48.7 \%$ lived in a province for the longest time, $74.0 \%$ had middle income, $79.3 \%$ had nuclear family, $75.4 \%$ were raised in a democratic and safe family environment, and $49.3 \%$ had a moderate-level academic achievement. It was also found that $52.0 \%$ of students had not previously had information about the empathic tendency and among students who received information about the empathic tendency, $93.1 \%$ had the knowledge through university courses.Conclusion: No significant difference was determined between the descriptive characteristics of students and their knowledge about the empathic tendency and ETS mean scores. The empathic tendencies of students were moderate.
\end{abstract}

Keywords: Empathic tendency, midwifery students, midwifery education.

${ }^{a}$ Atatürk Üniversitesi, Sağlık Bilimleri Fakültesi, Ebelik Bölümü

Geliş Tarihi:19.10.2014 / Kabul Tarihi:02.01.2015

Yazışma adresi:Hediye Bekmezci, Atatürk Üniversitesi, Sağlık Bilimleri Fakültesi, Ebelik Bölümü,

hediye.bekmezci@hotmail.com 


\section{Giriș}

İnsan; yaşamı boyunca çevresiyle etkileşirken öğrendiklerini, çevresindeki diğer insanlara ve kendinden sonra gelen kuşaklara aktarabilen, toplumsal bir varlıktır. Bunu sağlayan ise insanın sahip olduğu iletişim yeteneğidir. ${ }^{1} \quad$ Etkili kişilerarası ilişkiler kurma, yardım etme ve danışmanlık becerileri bir ebenin edinmesi gereken davranışlardır ve kaliteli ebelik bakımının ön koşullarıdır. Anlaşılmak temel insan gereksinmelerinden biridir ve bireyi doğru bir şekilde anlama ebe/hemşirenin empati becerisiyle ilişkilidir. ${ }^{2,3}$

Empati, bir fikir almak ya da başkalarının duygularını anlama yeteneğidir. Empati, başka insanların duygularını yaşadığımız anlamına gelmez, diğer insanların duygularını deneyimlerimiz yardımıyla anlamak anlamına gelir. Empati, kendi kişiliğini yok ederek başka bir kişiliğe girmek anlamını kapsamamaktadır. Bireylerin gerçeği nasıl algıladıkları hakkında bir duyguya sahip olabilmek için ruhen ve zihnen bu yönde hareket etmektir. ${ }^{4}$ Empati kurma sürecinin ilk adımı etkin dinlemedir. Empati kurulacak kişi mümkün ve gerekli olduğu kadar çok kanaldan dinlenmeli, düşünceleri, tutumları ve duyguları anlaşılmaya çalışılmalıdır. Etkin dinleme yapabilmek empati kurmayı önemli ölçüde kolaylaştırır ama empati kurmak için bu tek başına yeterli değildir. Empati kurmak için, özellikle tutum ve duyguların anlaşılmasına odaklanılmalıdır. ${ }^{2}$

Ebeler ve hemşireler hastalara empatik bir tutumla yaklaştıklarında onların gereksinimlerini daha doğru saptayabilir ve bakım gereksinimlerini etkili bir şekilde karşılayabilirler. Ebe ve hemşire tarafından anlaşıldığını hisseden birey önemsendiğini, ona güvenildiğini ve değer verildiğini düşünür. $\mathrm{Bu}$ durumda ebenin/hemşirenin bireye ulaşması kolaylaşır ve birey ebenin/hemşirenin bakımını kabul eder. Dolayısıyla bireyselleşmiş bakım ve olumlu tedavi edici ortam sağlanmış olur. Bireye verilen bu tür bir hizmet sonrasında iyileşme hızı artar, tedavinin olumsuz sonuçları azalır. $^{2,3,5-7}$ Öz; hemşirelerin danışana yardımcı olabilmelerinin, empatik eğilime sahip olmaları ve empatik becerilerini yeterli düzeyde geliştirmeleri ile mümkün olacağını vurgulamaktadır. ${ }^{8}$

Empatik eğilim bireyin empati yapabilme potansiyelidir. Empatik eğilim, danışanın duygularını anlama ve duygusal yaşantılarından etkilenme yeteneği, yardım etme isteği olarak belirtilmektedir. Rogers; empatik eğilimi, sosyal duyarlılık olarak tanımlamıştır. Sosyal duyarlılığın bir kişilik özelliği olduğunu ve her insanda bulunmadığını, sosyal duyarlılığa sahip bireylerin daha fazla empatik olabileceklerini ve empatiyi kolayca öğrenebileceklerini belirtmiştir. ${ }^{9}$ Dökmen; empatik eğilim ile yardım etme davranışı arasında olumlu bir ilişki olduğunu ve empatik eğilimi yüksek insanların yardım davranışını daha fazla gösterdiklerini belirtmektedir. ${ }^{10}$ Empatik eğilim, kişinin günlük hayatta empati kurma potansiyelidir. Empatik eğilim, karşıdaki kişinin hissettiği duyguları anlayabilme ve bu kişilerin duygusal yaşantılarından etkilenme yeteneğini yani, o bireyin duygusal boyutta yerine geçebilme yatkınlığını ve yardım etme isteğini içerir. ${ }^{11}$

Bireyin günlük yaşamda, yardım edicilik düzeyini belirleyen empatik eğilimin kazanılması uzun bir süreç gerektirir. $^{12}$ Öz ${ }^{13}$ yaptığı bir çalışmada; haftada iki saat olmak üzere 10 haftalık sürede verilen empati eğitimi sonucunda hemşirelerin empatik iletişim becerilerinin geliştiği, buna karşılık empatik eğilim düzeylerinin değișmediğini belirtmiştir. ${ }^{12}$ Empatinin önemli bir boyutunun taklit etme olduğu, davranış, biliş ve duygulanımda benzerlikler oluşmasına olanak sağladığı, taklidin sosyal çevremizi algılama ve iletişim kurmada etkisinin yüksek olduğu ifade edilmektedir. ${ }^{14}$

Ülkemizde literatür incelendiğinde hemşirelik öğrencilerinin empatik eğilimlerine yönelik araştırmaların olduğu, 
fakat ebelik öğrencileri ile ilgili bu konuda yeterli çalışmanın olmadığı görülmüştür. $\mathrm{Bu}$ gereksinim doğrultusunda araştırma, ebelik bölümü öğrencilerinin empatik eğilimlerini değerlendirmek amaciyla tanımlayıcı olarak yapılmıştır.

\section{Gereç ve Yöntem}

Tanımlayıcı tipte olan çalışma; Atatürk Üniversitesi Sağlık Bilimleri Fakültesi Ebelik Bölümü öğrencileri ile 2013-2014 eğitim-öğretim bahar yarıyılında gerçekleştirilmiştir. Ebelik bölümünün öğrenim süresi 4 yıl, 8 sömestr olup, teorik ve uygulamalı eğitimi içermektedir. Çalışmanın evrenini 175 ebelik öğrencisi oluşturmaktadır. Formları hatalı dolduran, verilerin toplandiğı tarihte okulda bulunmayan ve çalışmaya katılmayı kabul etmeyen öğrenciler örneklem diş1 bırakılmış ve 150 öğrenci ile çalışma tamamlanmıştır.

\section{Veri Toplama Araçları}

$\mathrm{Bu}$ araştırmada kullanılacak veri toplama araçları; araştırmacılar tarafindan oluşturulan "Tanıtıcı Bilgi Formu" ve " Empatik Eğilim Ölçeği” dir.

Tanitıcı Bilgi Formu; Araştırma verilerinin toplanması için araştırmacılar tarafından oluşturulan öğrenci ebelerin sosyo-demografik özelliklerini içeren (15 soruluk) tanıtıcı bilgi formu kullanılmıştır. Tanıtıcı Bilgi Formunda öğrencilerin sınıfı, yaşı, aile tipi, ekonomik durumu, ailesinin eğitim durumu, büyüdüğü yetiştiği yer, akademik başarı algısı, bilgisayar kullanma durumu, empati konusunda eğitim alıp almadığı ile ilgili sorular yer almaktadır.

Empatik Ĕ̆ilim Ölçeği (EEÖ);Prof. Dr. Üstün Dökmen tarafından 1988 yılında geliştirilmiş olan ölçek kişilerin günlük yaşantılarındaki empati kurma potansiyellerini ölçmek üzere geliştirilmiş likert tipi bir ölçektir. Empatik Eğilim Ölçeğinin geçerlik güvenirlik çalışması yapılmış olup, güvenirlik katsayısı 0,82 olarak bulunmuştur. Yapılan bu araştırmada cronbach alfa kat sayısı 0.75 olarak belirlenmiştir. Birey, her bir maddenin yanındaki 1'den 5'e kadar olan sayılardan birini işaretleyerek, ilgili maddedeki görüşe ilişkin katılımlarını ifade etmektedirler. İşaretlenen sayılar o maddeye ilişkin puanları oluşturmaktadır. Alınabilecek en yüksek toplam puan 100, en düşük puan 20'dir. Toplam puanın yüksek olması empatik eğilimin yüksek olduğu anlamını taşır. Doğru anlatımlardan oluşan maddelerin puanlanmasi; Tamamen aykırı (1 puan), Oldukça aykırı (2 puan), Kararsızım (3 puan), Oldukça uygun (4 puan), Tamamen uygun (5 puan) olarak belirtilmiştir.

Empatik eğilim ölçeğinde bazı ifadeler kişilerin "evet" deme eğilimlerini önlemek için negatif yazılmıştır ve tersine dönmüş ifadelerdir. Evet deme eğilimini önlemek için $3,6,7,8,11,12,13,15$. sırada yer alan ifadeler tersten yazılmıştır. $\mathrm{Bu}$ maddelere ilişkin puanlama ise; Tamamen aykırı (5puan) olmak üzere Tamamen uygun (1puan) olarak belirlenmiştir.

\section{Verilerin Toplanması}

Veriler 01.04.2014 ile 03.05.2013 tarihleri arasında araştırmacılar tarafından yüz yüze görüşme yöntemi ile toplanmıştır. Öğrencilere veri toplama araçları ile ilgili açıklamalar yapılarak araştırmanın amacı açıklanmıştır.

\section{Verilerin Analizi}

Verilerin analizi SPSS 18.00 istatistik paket programı ile yapılmıştır. Verilerin değerlendirilmesinde ortalama, yüzdelik, $\mathrm{t}$ testi ve varyans analizi kullanılmıştır.

\section{Çalışmanın Etik Yönü}

Çalışmanın yapılabilmesi için araştırmanın yapılacağ 1 fakültenin "Atatürk Üniversitesi Sağlık Bilimleri Fakültesi Etik Kurulu" ndan ve ilgili fakülteden izin alınmıştır.

Araştırmaya katılan kişilerin isim bilgilerinin verilmemesine etik olarak dikkat edilmiştir.

Araştırmaya katılan bireylere araştırmaya katılma ya da katılmama 
konusunda özgür oldukları konusunda bilgilendirilmiştir.

\section{Bulgular}

Araştırma kapsamındaki ebelik öğrencilerinin yaş ortalamasının $20.05 \pm 1.48$ olduğu bulunmuştur.

Araştırma kapsamındaki ebelik öğrencilerinin tanıtıcı özellikleri incelendiğinde; öğrencilerinin \%40.0'1nın birinci sınıf olduğu, \%83.3'ünün okul öncesi eğitim almadığ 1 \%48.7'sinin en uzun süre ilde yaşadığ1, \%74.0'ının orta düzeyde gelire sahip olduğu, \%52.7'sinin annesinin ve \%44.7'sinin babasının ilkokul mezunu olduğu, \%79.3'ünün çekirdek aileye sahip olduğu, \%75.4'ünün aile içinde demokratik, güven verici ortamda yetiştirildiği, \%49.3'ünün akademik başarısının orta seviyede olduğunu, \%55.3'ünün günlük 1 saat bilgisayar kullandığı saptanmıştır (Tablo 1).

Araştırma kapsamına alınan öğrencilerin tanıtıcı özelliklerine göre EEÖ toplam puan ortalamaları karşılaştırıldığında; 1. sınıf öğrencilerin puan ortalamas1 $69.10 \pm 8.48, \quad 4$. sinıf öğrencilerin ise puan ortalamas1 $70.29 \pm 10.17$ olduğu ve aradaki farkın anlamlı olmadı̆̆ (p>0.05, tablo 1).

Öğrencilerin okul öncesi eğitim alma durumları ile EEÖ toplam puan ortalamalarının karşılaştırılması değerlendirildiğinde; eğitim alan öğrencilerin puan ortalaması $69.84 \pm 7.15$, almayanların $68.80 \pm 9.33$ olarak bulunmuş ve aradaki farkın anlamlı olmadığ belirlenmiştir ( $p>0.05$, tablo 1$)$.

Öğrencilerin ebelik eğitimine başlamadan önceki yaşadığı yere göre EEÖ toplam puan ortalamaları incelendiğinde; köyde yaşamış olan öğrencilerin $70.44 \pm 8.80$, ilçede yaşamış olanların $66.93 \pm 8.15$ ve ilde yaşamışların ise $69.73 \pm 9.47$ olduğu ve aradaki farkın anlamlı olmadığı bulunmuştur ( $p>0.05$, Tablo 1).

Öğrencilerin annelerin eğitim durumu ile EEÖ toplam puan ortalamaları karşılaştırıldığında; okuryazar olmayan annelerin puan ortalamas1 68.72 \pm 9.36 , ilkokul mezunu olanların puan ortalaması $69.29 \pm 8.45$, ortaokul mezunu olanların puan ortalamas1 $70.71 \pm 11.20$, lise mezunu olanların puan ortalamasi $65.30 \pm 8.35$ olduğu ve aradaki farkın anlamlı olmadığ 1 bulunmuştur ( $p>0.05$, tablo 1$)$.

Öğrencilerin babalarının eğitim durumu ile EEÖ toplam puan ortalamalarının karşılaştııılması incelendiğinde; okuryazar babaların puan ortalaması $68.50 \pm 5.87$, ilkokul mezunu olanların $68.83 \pm 9.33$, ortaokul mezunu olanların $68.25 \pm 8.47$, lise mezunu olanların $70.03 \pm 10.08$, üniversite mezunu olanların $69.41 \pm 8.76$ olduğu ve aradaki farkın anlamlı olmadığı bulunmuştur (p>0.05, Tablo 1).

Öğrencilerin aile tipi ile EEÖ toplam puan ortalamaları değerlendirildiğinde; çekirdek ailede yaşayan öğrencilerin puan ortalaması $69.26 \pm 8.60$, geniş ailede yaşayan ögrencilerin puan ortalaması $67.90 \pm 10.44$ olarak bulunmuş ve aradaki farkın anlamlı olmadığ 1 belirlenmiştir ( $>0.05$, Tablo 1).

Ebeveynlerin çocuk yetiştirme tarzı ile EEÖ toplam puan ortalamaları karşılaştırıldığında; ilgisiz, kayıtsı, tutarsiz aileler $70.42 \pm 8.75$, demokratik, güven verici, destekleyici aileler $69.02 \pm 9.26$ ve baskıc1, otoriter, disiplinli aileler ise $67.86 \pm 7.99$ olarak belirlenmiş ve aradaki farkın anlamlı olmadığ bulunmuştur ( $p>0.05$, Tablo 1).

Öğrencilerin akademik başarılarını algılama durumları ile EEÖ toplam puan ortalamaları karşılaştırıldığında; durumunu kötü olarak algilayan öğrencilerin puan ortalamas1 $69.84 \pm 7.09$, orta düzeyde algilayanların $68.71 \pm 8.91$ ve iyi düzeyde algılayanların $69.11 \pm 9.53$ olarak bulunmuş ve aradaki farkın anlamlı olmadığ belirlenmiştir ( $p>0.05$, Tablo 1). 
Tablo 1. Ebelik öğrencilerinin tanıtıcı özelliklerinin EEÖ puan ortalamaları ile karşılaştırılması

\begin{tabular}{|c|c|c|c|c|}
\hline Özellikler(n=150) & $\mathbf{N}$ & $\%$ & EEÖ Ort \pm SS & Test ve p değeri \\
\hline $\begin{array}{l}\text { Devam Ettiği Sinıf } \\
\text { 1. Sinıf } \\
\text { 2. Sinıf } \\
\text { 3. Sinıf } \\
\text { 4. Sinıf }\end{array}$ & $\begin{array}{l}60 \\
35 \\
24 \\
31\end{array}$ & $\begin{array}{l}40.0 \\
23.3 \\
16.0 \\
20.7\end{array}$ & $\begin{array}{c}69.10 \pm 8.48 \\
68.25 \pm 10.05 \\
68.04 \pm 7.14 \\
70.29 \pm 10.17 \\
\end{array}$ & $\begin{array}{c}\mathrm{F}=0.380 \\
\mathrm{p}>0.05\end{array}$ \\
\hline $\begin{array}{l}\text { Okul Öncesi Eğitim Alma Durumu } \\
\text { Aldım } \\
\text { Almadım }\end{array}$ & $\begin{array}{c}25 \\
125\end{array}$ & $\begin{array}{l}16.7 \\
83.3\end{array}$ & $\begin{array}{l}69.84 \pm 7.15 \\
68.80 \pm 9.33 \\
\end{array}$ & $\begin{array}{c}t=-0.522 \\
p>0.05\end{array}$ \\
\hline $\begin{array}{l}\text { Uzun Süre Yaşanılan Yer } \\
\text { Köy } \\
\text { İlçe } \\
\text { İl }\end{array}$ & $\begin{array}{l}29 \\
48 \\
73\end{array}$ & $\begin{array}{l}19.3 \\
32.0 \\
48.7\end{array}$ & $\begin{array}{l}70.44 \pm 8.80 \\
66.93 \pm 8.15 \\
69.73 \pm 9.47\end{array}$ & $\begin{array}{c}F=1.905 \\
p>0.05\end{array}$ \\
\hline $\begin{array}{l}\text { Algılanan Gelir Düzeyi Durumu } \\
\text { Düşük } \\
\text { Orta } \\
\text { İyi }\end{array}$ & $\begin{array}{c}21 \\
111 \\
18\end{array}$ & $\begin{array}{l}14.0 \\
74.0 \\
12.0\end{array}$ & $\begin{array}{c}70.00 \pm 9.07 \\
68.51 \pm 8.83 \\
70.66 \pm 10.08 \\
\end{array}$ & $\begin{array}{c}\mathrm{F}=0.597 \\
\mathrm{p}>0.05\end{array}$ \\
\hline $\begin{array}{l}\text { Annenin Eğitim Durumu } \\
\text { Okuryazar Değil } \\
\text { İlkokul } \\
\text { Ortaokul } \\
\text { Lise } \\
\end{array}$ & $\begin{array}{l}47 \\
79 \\
14 \\
10\end{array}$ & $\begin{array}{r}31.3 \\
52.7 \\
9.3 \\
6.7 \\
\end{array}$ & $\begin{array}{c}68.72 \pm 9.36 \\
69.29 \pm 8.45 \\
70.71 \pm 11.20 \\
65.30 \pm 8.35\end{array}$ & $\begin{array}{c}\mathrm{F}=0.771 \\
\mathrm{p}>0.05\end{array}$ \\
\hline $\begin{array}{l}\text { Babanın Eğitim Durumu } \\
\text { Okuryazar } \\
\text { İlkokul } \\
\text { Ortaokul } \\
\text { Lise } \\
\text { Üniversite }\end{array}$ & $\begin{array}{l}10 \\
67 \\
31 \\
30 \\
12\end{array}$ & $\begin{array}{c}6.7 \\
44.7 \\
20.6 \\
20 \\
8.0\end{array}$ & $\begin{array}{c}68.50 \pm 5.87 \\
68.83 \pm 9.33 \\
68.25 \pm 8.47 \\
70.03 \pm 10.08 \\
69.41 \pm 8.76 \\
\end{array}$ & $\begin{array}{c}\mathrm{F}=0.167 \\
\mathrm{p}>0.05\end{array}$ \\
\hline $\begin{array}{l}\text { Aile Tipi } \\
\text { Çekirdek Aile } \\
\text { Geniş Aile }\end{array}$ & $\begin{array}{c}119 \\
31\end{array}$ & $\begin{array}{l}79.3 \\
20.7\end{array}$ & $\begin{array}{c}69.26 \pm 8.60 \\
67.90 \pm 10.44\end{array}$ & $\begin{array}{l}t=0.747 \\
p>0.05\end{array}$ \\
\hline $\begin{array}{l}\text { Ebeveynlerin Çocuk Yetiştirme } \\
\text { Tarzı } \\
\text { İlgisiz, kayıtsız, tutarsız } \\
\text { Demokratik, güven verici, } \\
\text { destekleyici } \\
\text { Baskıc1, otoriter, disiplinli }\end{array}$ & $\begin{array}{c}14 \\
113 \\
23\end{array}$ & $\begin{array}{c}9.3 \\
75.4 \\
15.3\end{array}$ & $\begin{array}{l}70.42 \pm 8.75 \\
69.02 \pm 9.26 \\
67.86 \pm 7.99\end{array}$ & $\begin{array}{c}F=0.355 \\
p>0.05\end{array}$ \\
\hline $\begin{array}{l}\text { Akademik Başarı Algı Durumu } \\
\text { Kötü } \\
\text { Orta } \\
\text { İyi }\end{array}$ & $\begin{array}{l}13 \\
74 \\
63\end{array}$ & $\begin{array}{c}8.7 \\
49.3 \\
42.0\end{array}$ & $\begin{array}{l}69.84 \pm 7.09 \\
68.71 \pm 8.91 \\
69.11 \pm 9.53\end{array}$ & $\begin{array}{c}F=0.097 \\
p>0.05\end{array}$ \\
\hline $\begin{array}{l}\text { Günlük Bilgisayarda } \text { Geçirilen } \\
\text { Süre } \\
\text { Bir saat } \\
\text { İki saat } \\
\text { Üç saat ve üzeri }\end{array}$ & $\begin{array}{l}83 \\
35 \\
32\end{array}$ & $\begin{array}{l}55.3 \\
23.4 \\
21.3\end{array}$ & $\begin{array}{c}69.59 \pm 7.97 \\
67.28 \pm 10.24 \\
69.25 \pm 10.07\end{array}$ & $\begin{array}{c}\mathrm{F}=0.824 \\
\mathrm{p}>0.05\end{array}$ \\
\hline
\end{tabular}


Tablo 2 Ebelik Öğrencilerinin empatik eğilim hakkındaki bilgi durumlarının EEÖ puan ortalamaları ile karşılaştırılması

Özellikler(n=150) n $\quad$ EEÖ Ort \pm SS $\quad$ Test ve p değeri

Empatik Eğilim Hakkında Bilgi Alma Durumu

\begin{tabular}{lrrrc} 
Aldım & 72 & 48.0 & $69.29 \pm 8.23$ & $\mathrm{t}=-0.406$ \\
Almadım & 78 & 52.0 & $68.69 \pm 9.69$ & $\mathrm{p}>0.05$ \\
\hline Empatik Bilgi Alma Türü (72) & & & & \\
Üniversitede Ders Olarak & 67 & 93.1 & $69.32 \pm 8.30$ & $\mathrm{~F}=0.252$ \\
Kitaplar & 2 & 2.7 & $73.00 \pm 7.07$ & $\mathrm{p}>0.05$ \\
Seminer & 3 & 4.2 & $70.33 \pm 14.01$ & \\
\hline
\end{tabular}

Öğrencilerin günlük bilgisayarda geçirdiği süre ile EEÖ toplam puan ortalamalarının karşılaştırılması incelendiğinde; bir saat geçiren öğrencilerin puan ortalaması $69.59 \pm 7.97$, iki saat geçirenlerin puan ortalaması $67.28 \pm 10.24$, üç saat ve üzeri geçirenlerin puan ortalamasi $69.25 \pm 10.07$ olarak belirlenmiş ve aradaki farkın anlamlı olmadı̆̆ bulunmuştur ( $\mathrm{p}>0.05$, tablo 1$)$.

Araştırmaya katılan öğrencilerinin empatik eğilim konusundaki bilgi alma durumları incelendiğinde; öğrencilerinin \%52.0'ının daha önce empatik eğilim hakkında bilgisi olmadığı ve empatik eğilim hakkında bilgi alanlar içinde \%93.1'inin üniversitede ders olarak aldığ saptanmıştır (Tablo 2).

Öğrencilerin empatik eğilim konusundaki bilgi alma durumları ile EEÖ toplam puan ortalamaları karşılaştırıldığında; bilgi alan öğrencilerin puan ortalamas1 $69.29 \pm 8.23$, almayan öğrencilerin puan ortalaması $68.69 \pm 9.69$ olarak bulunmuş ve aradaki farkın anlamlı olmadığı belirlenmiştir ( $\mathrm{p}>0.05$, Tablo 1).

Öğrencilerin empatik bilgi alma türü ile EEÖ toplam puan ortalamalarının karşılaştırılması incelendiğinde; üniversitede ders olarak alan öğrencilerin puan ortalamas1 $69.32 \pm 8.30$, kitaplardan bilgi alan öğrencilerin puan ortalaması $73.00 \pm 7.07$, seminer olarak alan öğrencilerin puan ortalamas1 $70.33 \pm 14.01$ olarak belirlenmiş ve aradaki farkın anlamlı olmadığı bulunmuştur $(\mathrm{p}>0.05$, Tablo 1).

\section{Tartışma}

Ebelik bölümü öğrencilerinin empatik eğilim puan ortalamaları incelendiği bu çalışmada, öğrencilerin empatik eğilim puan ortalamasinın orta düzeyde $68.98 \pm 8.99$ olduğu görülmüştür. Çakmak Demirbaş ${ }^{15}$ üniversite ögrencileri arasında yaptığı çalışmada aynı ölçeğin puan ortalaması 70.36 \pm 8.40 olarak, Piji Küçük ${ }^{16}$ müzik öğretmeni adayları arasında yaptığ 1 çalışmada $71.04 \pm 9.59$ olarak, Öz'ün ${ }^{8}$ son sınıf hemşirelik öğrencileri arasında yaptığı çalışmada ise $70.25 \pm 8.20$ olarak belirtmiştir. Sunulan araştırmalarda elde edilen empatik eğilim puan ortalamaları, yapılan bu çalışma bulguları ile benzer niteliktedir. Ebelik öğrencilerinin hasta bakımında temel oluşturacak olan empatik eğilimlerinin orta düzeyde olması, bu düzeyin daha ileri eğitimlerle geliştirilebilmesi açısından önemlidir. Ögrrencilerin ölçek ortalamasının üzerinde bir puan almış olmalarına rağmen ölçekten alınabilecek en yüksek puanın 100 olması ve sağlık hizmetlerinin temel felsefesinin yardım etmeyi amaçlaması düşünüldüğg̈nde, öğrencilerin empatik eğilimlerinin istendik düzeye ulaşması için geliştirilmesi gerekliliği ön görülmektedir. $^{17}$

Çalışmada birinci sınıf öğrencilerin empatik eğilim puan ortalamaları $69.10 \pm 8.48$, dördüncü sınıf öğrencilerin ise $70.29 \pm 10.17$ olarak tespit edilmiştir. Mete ve Gerçek $^{3}$ yaptığı çalışmada birinci sınıf ögrencilerinin empatik eğilim puan ortalamaları $74.19 \pm 8.26$, dördüncü sınıf $76.63 \pm 7.53$ olarak bildirilmesi araştırma 
bulgularını desteklemektedir. $\mathrm{Bu}$ sonuç; ebe adayların devam ettikleri sinıfların empatik eğilimi etkilemediğini göstermektedir.

Öğrencilerin aile tipi, uzun süre yaşanılan yere göre empatik eğilim puan ortalamaları arasında anlamlı fark bulunmamıştır. Benzer şekilde öğrenciler arasında yapılan diğer çalışmalarda da tanıtıcı özellikler ile empatik eğilim puan ortalamaları arasında anlamlı bir ilişki bulunmadığı belirtilmiştir. ${ }^{5,18,19}$ Sabancıoğulları ve ark. $^{5}$ öğrencilerin empatik eğilim puanları üzerinde mezun oldukları lise türü dışında diğer bireysel ve aile özelliklerinin etkisi bulunmadığını belirtmektedir.

Araştırmada, akademik başarı algı durumları ile EEÖ toplam puan ortalamalarının karşılaştırılması sonucu aradaki farkın anlamlı olmadığı belirlenmiştir. Öz $z^{8}$ empatik eğilim ve akademik başarı arasında pozitif yönde, istatistiksel olarak anlaml olmayan bir ilişki olduğunu bildirmiştir. Araştırma sonuçları benzerlik göstermektedir.

Araştırmada öğrencilerin, empatik eğilim konusundaki bilgi alma durumları ile EEÖ toplam puan ortalamaları arasında anlamlı fark olmadığı belirlenmiştir. Dizer ve İyigün ${ }^{20}$ yoğun bakım hemşireleri arasında yaptığı çalışmada hemşirelerin empati ile ilgili derse/konferansa katılma durumu ile empatik eğilim puan ortalamaları arasında istatistiksel olarak anlamlı fark saptanmadığı belirtmişlerdir. Mete ve Gerçek $^{3}$ hemşirelik öğrencileri arasında yaptığ empatik eğilim puanlarının değişmediği belirtilmiştir. Karaca ve ark. ${ }^{21}$ hemşirelik birinci sınıf ögrencilerine verilen empatik beceri eğitim programının empatik eğilim ve empatik becerilerinin gelişmesine etkisini belirlemek amaciyla yaptığı çalışmada, empatik eğilim puan ortalaması eğitim öncesi ön test ortalamas1 $68.45 \pm 6.81$ iken eğitim sonrası son test ortalamas1 $\quad 70.64 \pm 8.38$ olduğunu belirtmiştir. $\mathrm{Bu}$ sonuçlar araştırma bulgularını desteklemektedir. Empatik eğilim, empatinin duygusal boyutunu oluşturmakta olup doğuştan gelen bir kişilik özelliğidir. Empatik eğilimin bir beceri ya da bilișsel gelişimden çok tutum gelişimi ve kişilik değişimi gerektirmektedir. Bu özelliklerinden dolayı değiştirilmesi çok güçtür ve bunun için daha uzun süreli bir eğitime ihtiyaç vardır. ${ }^{3}$ Her ne kadar bir kişilik özelliği olsa da empatik eğilim ve empatik beceri, mesleki eğitim sırasında kazandırılmalı ve mesleki uygulamalarla da geliştirilmelidir. ${ }^{13}$

\section{Sonuç ve Öneriler}

Öğrencilerin devam ettiği sınıf, okul öncesi eğitim alma, uzun süre yaşadığı yer, algılanan gelir düzeyi, anne-baba eğitim durumu, aile tipi, ebeveynlerin çocuk yetiştirme tarzları, akademik başarı alg1 durumu ve günlük bilgisayarda geçirilen süre ile empatik eğilim puan ortalamaları arasında anlamlı fark bulunmamıştır. Öğrencilerin empatik eğilim puan ortalamalarına göre empatik eğilimlerinin orta düzeyde olduğu tespit edilmiştir.

Ebelik eğitiminde temel amaç, profesyonel ebelik uygulamalarının öğrenilmesidir. Öğrencilerin ebelik mesleğine özgü bilgi, beceri ve uygulamaları öğrenmesinin yanında etkili kişilerarası ilişkiler ve empati kurabilme, yardım etme, danışmanlık becerileri gibi temel becerileri de benimsemesi gerekmektedir. Bu nedenle, yüksek öğretim alan öğrencilerin empatik eğilim, empati ve iletişim becerilerinin belirlenmesi ve becerileri geliştirmeye yönelik derslerin etkinliğinin artırılması önemlidir. $\mathrm{Bu}$ etkinliği artırmaya yönelik öğrencilere; psikodrama, didaktik, model alma, sanat, yaratıcılık, iletişim vb. gibi konularda müfredat programına eklenecek seçmeli derslerin sunulması yararlı olabilir. Ayrica çalışma sonuçlarının öğrencilerle paylaşılması farkındalığı arttırarak motivasyonu güçlendirmeye katk1 sağlayabilir. 


\section{Kaynaklar}

1. Akça Ay F. Sağlık uygulamalarında temel kavramlar ve beceriler [Basic concepts and skills in medical practice]. 1. Baskı, İstanbul: Nobel Tip Kitabevleri; 2013. p.72,106.

2. Cevahir R, Çınar N, Sözeri C, Şahin S, Kuğuoğlu S. Ebelik öğrencilerinin devam ettikleri sinıflara göre empatik becerilerinin değerlendirilmesi [Evaluation of the empathic skills of midwifery students with respect to the classes they are attending]. Firat Sağlik Hizmetleri Dergisi 2008; 3(7):6-7.

3. Mete S. Gerçek E. PDÖ yönetimiyle eğitim gören hemşirelik öğrencilerinin empatik eğilim ve becerilerinin incelenmesi [The examination of empatic tendency and skills on nursing students who are educated with pbl method]. C.Ü. Hemşirelik Yüksekokulu Dergisi 2005; 9(2): 1117.

4. Badea L, Pana NA. The role of empathy in developing the leader's emotional intelligence. Theoretical and Applied Economics 2010; 543(2): 6978.

5. Sabancıoğulları S, Kelleci M, Doğan S, Gölbaşı Z. Entegre eğitim programında öğrenim gören hemşirelik öğrencilerinin empatik eğilim düzeylerinin y1llara göre incelenmesi [The empathic tendency in nursing students educated with integrated method according to the years]. Cumhuriyet Üniversitesi Hemşirelik Yüksekokulu Dergisi 2007;11(2):1-6.

6. Üstün B. Çünkü iletişim çokşeyi değiştirir! [Because communıcatıon has more changed]. Atatürk Üniversitesi Hemşirelik Yüksekokulu Dergisi 2005; 8: 88-94.

7. Reynolds W, Scott B. Do nurses and other professional helpers normally display much empathy? Journal of Advanced Nursing 2000; 31: 226-234.

8. Öz F. Son sınıf öğrencilerin empatik eğilimleri, empatik becerileri ve akademik başarıları arasındaki ilişki [The relations between empathic tendency, empathic skills and academic performance of senior students of nursing]. Cumhuriyet Üniversitesi Hemşirelik Yüksekokulu Dergisi 1998;2(2): 32-38.

9. Rogers CR. Empatik olmak değeri anlaşılmamış bir varoluş şeklidir [Be empathic is a way of being undigested value]. Çeviren: Akkoyun F. A.Ü. Eğitim Bilimleri Fakültesi Dergisi 1983;16(1):103-124.

10. Dökmen Ü. İletişim çatışmaları ve empati [Contact conflict and empathy]. 39. Basım, İstanbul: Sistem Yayıncılık; 2008. p. 119-150.

11. Çiçek A. Sağlık çalışanlarının empatik eğilim ve becerilerinin değerlendirilmesi [The evaluation of empathic tendencies and skills of heallth staffs] [Yüksek Lisans Tezi]. Marmara Üniversitesi Sağlık Bilimleri Enstitüsü [Institute of Medical Sciences, Marmara University], İstanbul, Türkiye, 2006.

12. Öz F. Hemşirelikte özgecilik [Altruism in nursing]. Cumhuriyet Üniversitesi Hemşirelik Yüksekokulu Dergisi, 1998; 2(1): 53-58.

13. Öz F. Hemşirelerin Empatik iletişim becerisi ve eğilimine eğitimin etkisi [Effect of training on nurses' empathic skills and empathic tendency] [Doktora Tezi]. Hacettepe Üniversitesi Sağlık Bilimleri Enstitüsü [Institute of Medical Sciences, Hacettepe University], Doktora Tezi, Ankara, 1992.

14. Van Baaren RB, Decety J, Dijksterhuis A, Van Der Leij A, Van Leeuwen ML. Being 1mitated: Consequences of nonconsciously showing empathy. Decety J, Ickes W. (Eds), The social neuroscience of empathy. Cambridge, MA, USA: MIT Press. 2009: 31-42.

15. Çakmak A, Demirbaş A. Review of the emphatic tendencies of university students in terms of some variables. International Journal of Humanities 
and Social Science 2014; Vol. 4, 7(1); 29-33.

16. Küçük Piji D. Müzik öğretmeni adaylarının empatik eğilimleri ile iletişim becerileri arasındaki ilişkinin incelenmesi [Determination of the relationship between empathic tendencies and communication skills in music teacher candidates] . 2nd International Conference on New Trends in Education and Their Implications Antalya:Sistem Kitabevi; 2011. p. 935-942.

17. Yiğitbaş Ç, Deveci SE, Açık Y, Ozan AT, Oğuzöncül AF. Sağlık eğitimi alan bir grup öğrencinin empatik eğilim ve becerisi [The empathic tendency and empathic skills of a group of students receiving health education]. S.D.Ü Sağlık Bilimleri Dergisi 2013;4(1):713.

18. Tutuk A, Al D, Doğan S. Hemşirelik ögrencilerinin iletişim becerisi ve empati düzeylerinin belirlenmesi [Determining communication skills and emphatic levels of nursing students]. C. Ü. Hemşirelik Yüksek Okulu Dergisi 2002; 6 (2): 36-41.

19. Dereboy Ç, Harlak H, Gürel $S$, Gemalmaz A, Eskin M. Tip eğitiminde eşduyumu öğretmek [Teaching empathy in medical education]. Türk Psikiyatri Dergisi 2005; 16(2):83-89.

20. Dizer B, İyigün E. Yoğun bakım hemşirelerinde empatik eğilim düzeyleri ve etkileyen faktörler [The empathic tendency in the critical care nurses and the factors affecting]. Atatürk Üniversitesi Hemșirelik Yüksekokulu Dergisi 2009; 12(1):9-19.

21. Karaca A, Açıkgöz F, Akkuş D. Eğitim ile empatik beceri ve empatik eğilim geliştirilebir mi?: bir sağlık yüksekokulu örneği [Retrospectıve evaluation of the urgency of patients admitted to the emergency department by ambulance]. Acrbadem Üniversitesi Sağlık Bilimleri Dergisi 2013; 4(3): 118-122. 